From both a theoretical and practical standpoint, racism is one of the most important topics that has engaged the attention of social scientists in North America in recent years. As societies become more ethnically diverse, people from different cultures are increasingly coming into contact with each other, resulting in ever greater opportunities for racism to manifest itself.

In this work, Edith Samuel examines the educational experiences of South Asian students and faculty members from the perspective of 'integrative antiracism' - the study of how the dynamics of social difference are mediated in people's daily lives. Specifically, she analyses perceptions of and responses to racism in four critical areas: faculty-student relationships, peer group interactions, curriculum, and the psychosocial dimension.

Antiracism scholars maintain that racism is widespread on Canadian university campuses. Drawing on the available literature and extensive interviews with students and faculty, Samuel looks at both overt and covert forms of racism, as well as structural racism, that result in discrimination in admissions and employment. She also looks at race, class, gender, history, and culture and how these interlocking systems produce unique experiences of racism for South Asians in academe. Through the exploration of the intricate patterns of South Asians' assimilation into university life, Integrative Antiracism identifies the numerous barriers racial minorities encounter and suggests a variety of approaches to fostering a more equitable education system.

EDITH SAMUel is an assistant professor in the Department of Psychology at Atlantic Baptist University. 
This page intentionally left blank 


\section{EDITH SAMUEL}

\section{Integrative Antiracism:}

\section{South Asians in Canadian}

Academe

FOREWORD BY GEORGE DEI 


\section{www.utppublishing.com}

(C) University of Toronto Press Incorporated 2005

Toronto Buffalo London

Printed in Canada

ISBN-13 978-0-8020-3944-6 (cloth)

ISBN-10 0-8020-3944-8 (cloth)

ISBN-13 978-0-8020-3782-4 (paper)

ISBN-10 0-8020-3782-8 (paper)

(6)

Printed on acid-free paper

\section{Library and Archives Canada Cataloguing in Publication}

Samuel, Edith, 1947-

Integrative antiracism : South Asians in Canadian academe / Edith Samuel ; foreword by George Dei.

Includes bibliographical references and index.

ISBN 0-8020-3944-8 (bound). ISBN 0-8020-3782-8 (pbk.)

1. Discrimination in higher education - Canada. 2. South Asian college students - Canada. I. Title.

LC3479.S24 $2005 \quad 378.1^{\prime} 9829914071 \quad$ C2005-903608-7

University of Toronto Press acknowledges the financial assistance to its publishing program of the Canada Council for the Arts and Ontario Arts Council.

University of Toronto Press acknowledges the financial supports for its publishing activities of the Government of Canada through the Book Publishing Industry Development Program (BPIDP). 